\title{
Peranakan Chinese SPEeCH AND IDENTITY
}

\author{
by John U. Wolff
}

\section{Introduction}

It is perhaps not well known and certainly not a salient fact to outsiders that the Peranakan Chinese of Central Java have their own speech which is peculiar to themselves and not used by other populations resident there. The Peranakan are the people of Chinese descent who have been long-settled in Java and are not native speakers of a Chinese language. The designation "Peranakan" is opposed to the term "Pribumi," which refers to the Javanese people who do not claim foreign descent. The Peranakan language is not a different language from the Javanese of the Pribumis. In grammar, morphology, and syntax this speech differs only in minor ways from other typical Javanese dialects (although it is by no means isomorphic with the particular Javanese dialects spoken in Central Java by the Pribumi). In lexicon there are differences, and these differences have a role as indicators of ethnic and class identity. First, there is a small number of forms of Chinese origin not used by the Pribumi, and these are salient because of their meanings and high frequencyof use. Being of Chinese origin, specific to the Peranakan, and deployed in in-group speech, they clearly are used to place the speaker and the interlocutor as ethnic Peranakan. ${ }^{1}$ Second, there is a another set of forms of Dutch origin, of high frequency in Peranakan but not normally found in Pribumi speech, and these can be found in conversations with interlocutors of any ethnicity. The motivation for the existence of these forms can be undertstood from the role of Dutch as a prestige language in Indonesia in colonial times. ${ }^{2}$

\footnotetext{
1 A listing of some of these is given in J. U. Wolff and S. P. Poedjosoedarmo, Communicative Codes in Central Java (Ithaca, New York: Cornell Southeast Asia Program, 1982), p. 98.

2 An example of how Dutch forms are employed as a strategy for appropriating prestige comes from this sentence taken from the conversation of a Peranakan woman with her landlady. She explains that her relative has to stay with her in Salatiga temporarily because of health problems. As background it should
} 
30 John U. Wolff

These forms are important as being emblematic of identity, but they certainly do not shape the character of the language in any basic way. However, there is a characteristic of this speech, which if it were widely known would surely be remarked upon, and which, if one sees it in transcription, makes one realize that one is dealing with a way of speaking which is clearly recognizable as something apart from a normal Javanese dialect as spoken by Pribumis. This characteristic is the enormous amount of material from Indonesian which is deployed alongside the Javanese in normal everyday speech. This material is mainly lexical, but there are syntactic features as well. While it is true that Pribumi Javanese speakers, just as much as the Peranakan, are widely bilingual and that bilingualism is a societal phenomenon in Java- that is, many Javanese, probably almost all urban Javanese, use both Javanese and Indonesian in their day-to-day interactions, not only with outsiders, but also with other Javanese and and even within the family and circle of intimates ${ }^{3}$-the Pribumi way of mixing Javanese and Indonesian differs sharply in all aspects from the Peranakan way of mixing the two languages.

It is this difference which I would like to focus upon and explore the significance of in this paper. The difference is not a matter of chance. The language has taken this form as a result of the socio-historical context in which it developed. It is my aim to show how social needs of the speakers have created the form which the language has taken. I start from the premise that a function of variation in language is to create the social structure which enables us to cooperate. We place ourselves vis-à-vis one another very largely through language, and we use variation as a way to negotiate position. ${ }^{4}$ Language does not just reflect social relations. We may view language as creating them: if I address someone by first name, I am not just reflecting a feeling of intimacy with that person, I am creating a sense of intimacy; and if I refer to that person with name and title, I am not just referring, I am in fact creating a feeling of formality, distance, respect, or whatever such a way of speaking connotes. Further, this way of addressing allows me to claim certain rights or persuade my interlocutor that I

be noted that the interlocutor is a Pribumi woman who makes no secret of her low opinion of Chinese. This sentence is replete with forms designed to infuse prestige, including the Dutch-derived forms italicized. Their employment is certainly motivated by the tension caused by the feeling that the interlocutor despises the speaker. It should be noted that in fact the Dutch-derived form forlopikh "temporarily" is employed in addition to the normal word for "temporarily" in the sentence

Om Kwé tempatnya forlopikh di sini dulu. Dia kan swak to.

/Uncle Kwe his-place temporarily in here temporarily he you-know sick you-see/

"Uncle Kwe, his place for the time being is here for the while. He has been sick, you know"

The use of Indonesian rather than Javanese must be remarked on as well. Javanese with a high-status Pribumi would reqire the employment of Kromo, the Javanese high speech level, which unequivocally indicates a buying into the Javanese value system and a desire to identify with Javanese. The speaker is not prepared to expose herself to the humiliation of rejection which this might occasion (even if she did control the Javanese Kromo forms) Further, it is not by accident that she refers to her relation with the title $O m$, which among the Pribumi is given to non-Javanese. We happen to have a sentence addressed to a Peranakan student, a PhD candidate, who has high prestige, which offers a comparison (see example number 4 in the text below).

${ }^{3}$ J. U. Wolff and S. P. Poedjosoedarmo, Communicative Codes in Central Java, chapter 3.

4 Carol Myers-Scotton, "Social and Structural Factors in Codeswitching," Language in Society 22 (1993): 475-503. 
have them, and obliges me to do certain things. ${ }^{5}$ Analogously, we may view the Chinese and Dutch loan words discussed above as strategies for putting the speaker and interlocutor in a specific ethnic or class position. By similar reasoning we may hypothesize that the peculiar Indonesian-Javanese mixture current in the Peranakan Chinese community has a social function. This raises questions of what this function is, what this way of speaking tells us about the Peranakan Chinese community, where it originates, and why it has come to take the form that it has taken.

\section{Mixtures of Indonesian and Javanese}

Before we go on to answer these questions, let me first document my assertion that Peranakan and the Pribumi differ sharply from one another in the way they mix the Indonesian and Javanese elements. Let us look first at the mixture of Indonesian and Javanese in Pribumi speech. (We may term it "code-switching.") If we look at a sample of Pribumi speech that mixes Indonesian with Javanese, we note that the sentences are basically Javanese and the code switches are excursions into Indonesian, constituents (phrases or clauses) in Indonesian set in the midst of Javanese. In other words, there is a tendency to switch at specific points in the sentence which mark phrases or clauses. At the same time, within the Indonesian constituents certain items remain in Javanese: these are the forms which clearly indicate the speech level. The speech levels function much as the T-V ( $t u, v o u s$, in French) distinction in European languages, where relative status and intimacy are indicated by the choice of term of address and verb inflection (what has been termed the "semantics of power and solidarity"). ${ }^{6}$ In Javanese these distinctions are not marked just by the pronouns and the verbal morphology which agrees with the pronouns, as in European languages, but they are marked by words from throughout the vocabulary and, most saliently, words of high frequency-words like the deictics, the words for "yes" and "no," and other forms which serve to clarify the order of the discourse. The forms indicating speech level are salient-that is, the members of the speech community pick up on them readily and react to them. In the cases of code-switching from Javanese to Indonesian, these salient forms remain in Javanese and are scattered through the Indonesian constituents of the utterance. I would suggest that the function of retaining these in Javanese is twofold: first, to clarify the fact that the speaker and interlocutor identify with Javanese ethnicity and, second, to place the participants socially by specifying "speech level."

The following two sentences may illustrate this typical code-switching among the Pribumi. The first is spoken by a man to a woman who is trying to borrow money from him. The wider context makes it clear that the man has little respect for the woman. Apparently they had intimate relations at some time in the past. The man need not monitor his speech, but he still respects her feelings, and in order to convey a message which the woman might well find offensive, he switches to Indonesian. This switch to Indonesian puts the message on an impersonal, scientific, unemotional, or uninvolved level. Most important to note, however, is that both participants in the conversation are ethnically Javanese and as such feel constrained to indicate unequivocally their personal status vis-à-vis each other and the fact that they identify themselves and each

\footnotetext{
${ }^{5}$ See also John Gumperz, Discourse Strategies (Cambridge: Cambridge University Press, 1982).

${ }^{6}$ R. Brown and A. Gillman, "The Pronoun of Power and Stability," in Style in Language, ed. T. Sebeok (Cambridge, MA: MIT Press, 1960).
} 
other as Javanese. Thus, the Indonesian phrase is interspersed with Javanese forms which indicate both these factors. As we see, they are Ngoko, the lowest level, the most intimate level of Javanese, used to address a person with whom one feels the least inhibition. The sentence starts out in Javanese, but at the beginning of the second clause it switches to Indonesian. (In this illustration and others following, Indonesian is put in italics, and Javanese left in Roman script. In the translation the English words which translate the Indonesian forms are italicized and the ones which translate the Javanese forms are kept in Roman script.) Note that néng "but," yho "OK?, you agree with me?" nèq "if," ngantèq "to the point that," $k u$ "my," and $m u$ "you" are Javanese and clearly at the lowest speech level - that is, they are forms which can only be used with intimates or people whom one relegates to the level of a child in an adult-to-child relationship. In this conversation these forms signal that the speaker feels no need to be careful or considerate. The forms $k u$ and $m u$ are in fact homonymous with Indonesian words, but here they carry the same connotations as the other purely Javanese forms.

1 Kuwi, wektu kuwi . . . néng maqaf, yho, nèq katakataku nanti, jangan-jangan ngantèq menyinggung perasaqanmu, maqaf, yho?

/ that time that . . . but excuse-me OK, if my-words will, I-hope-it-doesn't-get-to-thepoint-of hurting your-feelings excuse-me OK/

"At that time ... but . . you'll have to excuse me, OK, if what I say . . . if it turns out to be something that hurts your feelings, excuse me, OK?"

The following illustration is an excerpt of a conversation between teachers. They are not intimate, consider each other people of high status, and speak at the highest level of Javanese. (They are constrained to be careful.) The subject matter is something normally discussed in Indonesian, and this accounts for the switch into Indonesian, which comes at the beginning of an attributive phrase. However, since Javanese is obligatory among Javanese to indicate identity of the self and the interlocutor as Javanese, and further, since status and relation must be overtly expressed, the sentence contains forms which clearly signal ethnic identity as Javanese and unequivocally give speech level (denote social relations). (Italics are used to show Indonesian forms and their translations, and Roman is used for the Javanese forms and their translations, as in the previous example.) The beginning of the excerpt continues Javanese, the mode of discourse between the two speakers, and then there is an abrupt switch to Indonesian under the influence of the topic of the conversation. Note that the form meniko, a deictic meaning something like "the" or "this, that" is clearly Javanese and salient in the sentence as an indicator of the highest speech level. The deictics in Javanese, and in Indonesian as spoken by Javanese, have a second function as markers of a conditional clause, as in the case of this occurrence. This form is of extremely high frequency and exists in several variants to express the height of the speech level aimed at.

2. Wonten malih anu meniko, masalah laré yhang nilénya kurang begitu baéq ato anaq yhang dhatang meniko bisa dhiterima.

/There-is also, umm this, problem a-child who his-grades not-so very good or child who comes that can be accepted/

"/There is this other matter ..., the problem of a child whose grades are not good or the case of whether the child that comes can be accepted. 
Note in this sentence, as in number 1, above, the switches to Indonesian and back take place at phrase or clause boundaries except where salient Javanese forms are sprinkled into the discourse as just discussed.

If we compare these two examples with the typical mixture employed by the Peranakan, we note that among the Peranakan the two languages are intertwined in a continuous switching back and forth, not at the level of a phrase or sentence constituent as is the case for the Pribumi, but at the word level. Single expressions consisting of a Javanese and an Indonesian form are normal and widespread: rong kali "twice," ndèq kemarèn "yesterday," danggoné "at." Since the aim is not to indicate Javanese identity and status is not clarified by Javanese speech level usage, the salient forms are not put into Javanese, as happens in the Pribumi Javanese-Indonesian mixture. We see that the salient forms are in Indonesian, and if putting something in Javanese creates ethnic identity and social status for the Pribumi, we may hypothesize that putting something into Indonesian does the analogous thing for the Peranakan Chinese. In the following illustration we see the deictic itu in Indonesian (cf. the use of the Javanese meniko in the Pribumi example, no. 2, above); also the particle asking for confirmation yha is Indonesian in form (cf. the Javanese yho of example 1 above); also sudah "completed aspect marker" and ada "there are" are salient forms put in Indonesian. The verb is also Indonesian but given a Javanese inflection.

3. Mamaé itu sudah rondo, dadiné ngerjaqno japét Itu séng njladrèni, yha, sudah diwarai. Ada séng mboq-mboq kan sudah biasa, El, wong lé bikén sudah suwi, yha.

/Her-mother that by-now widow, so she-makes cakes. That the-one-who makesdough, follow-me-, has-been taught. There-are some old-women you-know by-now know-how, [name], because action-of making by-now long-time, you-know-what-Imean/

"Her mother whom I just referred to is a widow now, so she makes "japet" [a kind of cake for sale]. Those people who make the dough, you know what I mean?, are already experienced. There are some old women, who are already experienced, El, because they have been making it for a long time, you follow me?'

This sentence is typical of relaxed Peranakan speech among Peranakan interlocutors. There is a point to note about the above sentence: the words of high frequency - words like the deictics, the words for "yes" and "no," and other forms which serve to clarify the order of the discourse are in Indonesian. That is, precisely the forms analogous to the ones which in Pribumi speech are salient and put into Javanese in order to clarify ethnic identity and relative status are here put into Indonesian. It is reasonable to conclude that motives prompting the Peranakan speaker to choose Indonesian are analogous to the motives prompting the Pribumi speaker to choose Javanese: indication of status and Peranakan identity.

\subsection{Other Differences in Pribumi and Peranakan Code-Switching}

Another point to make is that the system morphemes (principally the verbal affixes, genitive markers, nominal phrase markers) in Peranakan speech always remain in Javanese. It is the content words which may be in Indonesian. On the other hand, in Pribumi speech, when a speaker makes an excursion into Indonesian by introducing an Indonesian phrase or clause, the system morphemes are in Indonesian; they never are 
34 John U. Wolff

put into Javanese in an Indonesian phrase or clause. This feature saliently distinguishes the two different kinds of speech to the hearer and makes the employment of Peranakan mixed Javanese Indonesian an unequivocal indicator of ethnic identity: the Peranakan speech never contains Indonesian system morphemes (verbal affixes, genitive markers, and nominal phrase markers), whereas Pribumi speech contains these normally in the portions of the utterance which are switches into Indonesian. Illustrations of these Javanese system morphemes appear in all our exemplary sentences. As an example we could take the Javanese genitive marker é in example 5 (Peranakan):

Céq Kwé, tempaté

/Uncle Kwé place-his /

"Uncle Kwé's place"

This can be contrasted with the Indonesian genitive marker -nya of example 2 (Pribumi)

yhang nilénya kurang begitu baéq

/the-one-who his-grades less so good/

"whose grades are not so good"

I would attribute the motivation of putting system morphemes into Javanese or not as being their non-salience in speech: they are left in Javanese in Peranakan speech precisely because they are not noticed and do not have the force of content words in negotiating position (indicating identity); and in the Pribumi switches to Indonesian the system morphs are included in the switch also because of their lack of salience and lack of power in indicating status or Javanese identity.

\section{Choice of Indonesian as an Indication of Participant Status}

A close analysis of the speech of participants in conversations gives us further evidence that status is implicated in the choice of Indonesian among the Peranakan. Speakers who must be careful, on less-than-relaxed behavior, use more Indonesian admixture. In the conversation from which the above excerpt was taken, speech is addressed to the daughter-in-law, who is visiting the husband's mother with two grandchildren. The conversation reveals that they do not know each other well, and there is a great deal of Indonesian in the speech of both the mother-in-law and the daughter-in-law to each other. However, the mother uses almost 100 percent Javanese to her own children, who are present, and to a Javanese woman who is selling rice, whose store is the locus of the recording. A person who wishes to present himself or herself as a person of substance increases the amount of Indonesian admixture into the Javanese matrix. ${ }^{7}$ In another conversation between a college student and his great aunt recorded at a wedding party, the great aunt uses no Indonesian forms to her greatnephew and only a few to other guests at the party; the college student uses

7 The term "matrix" is used in a technical sense here. When there is language mixture within a phrase, the basic language is the "matrix." Forms from the second language are code switches. (See Scotton, "Social and Structural Factors," pp. $484 \mathrm{ff}$.) Characteristic of a "matrix" language is that the system morphemes (the inflectional affixes, genitive markers, etc.), phonology and syntax come from it, whereas the switched language normally does not supply any of this basic grammatical aparatus. We discuss this point below. 
Indonesian forms in every single sentence. ${ }^{8}$ Further, the status of an interlocutor as a person of substance calls for Indonesian admixture. This may be illustrated by the following sentence, spoken during this same event, where the great aunt speaks to a child with pure Javanese and then to another lady at the party, offering her food. The lady is addressed with Javanese and some Indonesian mixture.

4. Ta! Rita! He! He! Dikandani koq! Anaqé Cwan Tiong ki-jan! Heqe. Ini lho, So! Dijajal to So! ... Ha taqtanyaqi, yho moh ngono, oq!

/Ta! [name]. Rita Rita Hey! Hey! you-are-being-spoken-to hey! The-daughter ofCwan Tiong is-terrible! Yes. This, here, Ma'am. Take-it-to-eat please, Ma'am! Well, I-asked-you, well don't-want-it that's-what-you-said, you-did/

"Rita! Rita. Hey! Hey! They're talking to you. Cwan Tiong's daughter is really something. (to friend:) Uh-huh. Here, dear. Eat it, dear. . . Well, when I ask you, you say you don't want any!"

The same point can be seen in the following sentence which was uttered in the same scene as that presented in footnote 2 (in fact immediately following it). The statement is exactly the same, but this time it is addressed to a Peranakan PhD candidate (a person of high status). It is as if the sentence addressed to the Pribumi landlady would not be understood by the Peranakan, and it needed translating.

5. Céq Kwé tempaté dangkéné dulu.

"Uncle Kwé his place is here for the while."

Salient words are put in Indonesian, for the addressee has high status by virtue of his superior education, and the inconspicuous grammatical markers and half of the word meaning "be here" are in Javanese. Note also that "Uncle Kwé" is given a purely Chinese title (as opposed to the illustration in footnote two where the same person in a sentence addressed to a Pribumi is referred to by the title used by the Pribumi's "Om").

\section{Mixture as a Way of Expressing Identity}

As the outside observer reads the transcriptions of Peranakan in conversations with one another, it is possible to get the impression that the speakers have no control over which comes out - i.e., that they know both languages and aren't able to keep the two apart. Nothing could be further from the truth. A good portion of the material we recorded among the Peranakan was entirely in Javanese and demonstrated total control of Javanese. Further, personal experience with Peranakan speakers proves their ability to function in Indonesian with little or no Javanese slippage. The educated Peranakan of Central Java, like those of East Java, are good speakers of Indonesian. ${ }^{9}$ However, in interaction within the ethnic group, even the best speakers of Indonesian, like all the Central Javanese Peranakan, use this intertwined Indonesian-Javanese mixture. The obvious conclusion is that this mixture indicates ethnic identity. The

${ }^{8} \mathrm{~J}$. U. Wolff and S. P. Poedjosoedarmo, Communicative Codes, conversation 8, pp. 178- 181.

${ }^{9}$ E. Rafferty, "National Language Ability: A Socioeconomic Survey in East Java, Indonesia," Journal of Southeast Asian Studies 14, 1 (1983): pp. 134-138. 
36 John U. Wolff

indication of ethnic identity is a device for negotiating rights and obligations on the part of the participants in the conversation.

This mixture is not the only indicator of ethnic identity. As mentioned above, there is a substantial in-group vocabulary of Chinese origin which is also an ethnic marker. In addition, there are features of the syntax, morphology, phonology, and the lexical choices in Javanese words which clearly distinguish the Peranakan from the Pribumi and can indicate ethnicity, but they do not as clearly indicate interlocutor ethnicity as do the forms of Chinese origin and the use of the Javanese-Indonesian mixture. These are not necessarily under the speaker's conscious control, for they are occasionally present in speech addressed to Pribumi as well as in in-group speech. In syntax we should note the word order in phrases consisting of a demonstrative plus noun: the demonstrative in Pribumi Javanese comes after the noun, but in Peranakan Javanese it comes variably preceding or following the modified noun. Further, séng, a marker introducing an embedded attribute, is optionally dropped in Peranakan speech (but never in Pribumi speech) when there is a demonstrative modifying the phrase. The following sentence from the great-aunt at the party quoted in example 4, above, illustrates this:

6. Kuwi nyónya nganggó klambi ijó

/that lady wearing dress green/

"That lady who is wearing a green dress."

In Pribumi Javanese, kuwi "that" would have to come at the end of the phrase, and there would have to be a form séng to link the attributive phrase nganggo klambi ijó "wearing a green dress" to the word modified, nyonya "lady." The Pribumi version of this sentence is as follows:

(Pribumi) Nyónya séng nganggo klambi ijó kuwi

/Lady the-one-who wearing dress green that/

"That lady who is wearing a green dress"

For morphological features which indicate Peranakan identity, we note affixes from outside of Central Java (e.g. -qno "transitive verb marker," whereas Pribumi always has -qké. This is illustrated by the form ngerjaqno "make [transitive]" in example 3 -although the root in this illustration happens to be an Indonesian word, rather than a Javanese word). There is also special Peranakan morphology of Indonesian roots which clearly identifies the speech as Peranakan-that is, verbal affixes like other system morphemes are in Javanese, not Indonesian, even when used with Indonesian roots. (Verbal roots as content morphemes may be in Indonesian or Javanese.) An example is ngerjaqno "makes" from example 3, just discussed, and taq tanyaqi from example 4, above, meaning "I asked her," where the root tanya is Indonesian and the verb prefix taq and the verb suffix $-i$ is Javanese and not Indonesian. The morphophonemics (insertion of $/ q$ / between the root and the suffix) are also Javanese.

On the level of phonology which indicates Peranakan identity we can point to insertion of glottal stops and lowering of vowels, phonological processes characteristic of East Javanese dialects, but not of Central Java Pribumi speech. In lexicon we can 
point out numerous East Javanese forms not found in Central Java in Pribumi speech: kambéq "with" $i k u$ "that," and so forth.

\section{Melayu, the Lingua Franca, and Chinese Identity}

The history of the Chinese community in Indonesia and colonial policies make it fairly obvious why words of Chinese origin should become emblematic of Peranakan Chinese identity. To understand the parallel, one only has to think of the Spanish greetings "Hola. ¿Qué tal?," meaning "hi, how are you?" used by English speakers who have reason to identify with Hispanics (or andale! "go ahead!" associated with Chicanos) or the Yiddishisms common in New York for identification with Jewish ethnicity. Less obvious is the reason for the existence of this peculiar intertwining of Indonesian and Javanese, which we believe also serves to indicate Peranakan Identity.

The first point to consider is the historical role in colonial times (and even earlier) of Indonesian (or Melayu, as it was called at the time) as a lingua franca. It was not the language of any particular ethnic group, but a language in which ethnic groups freed themselves from the narrow confines of their identity. A version of this lingua franca became the language of the creolized ${ }^{10}$ urban populations who transcended any narrow ethnicity, and another version became the language of the print media which reported the events of the modern world, addressed not to a single ethnicity but to the members of a plural society. As Siegel writes:

Melayu was the language of the plural society, used between "natives" speaking different local languages and between them and Indos and Dutch. It was the tongue that connected most of the "native" world with Europeans and European culture as well as the rest of the world outside their local comunities. It was the language of authority, meaning not only governmental but also sometimes parental authority: in the major cities, Melayu became a creole, the first language of many speakers. ${ }^{11}$

Melayu became the vehicle with which the world at large was brought to the Indies. It was the language of print media dealing with modern life: "Melayu, the lingua franca, began to bring to the Indonesians the literatures and the events of the world and of one's neighbors." 12

In short, we see that Melayu had come to occupy a special function in the Indies by the end of the last century as the language of an interethnic community, the medium of a new non-ethnic culture, and the vehicle for connecting the people of the Indies to modernity. This special function of Melayu stems from a tradition which is a great deal older. It is not hard to understand that the Peranakan Chinese should sieze on Melayu,

\footnotetext{
10 It should be pointed out that the term "creole" is not here understood in its technical linguistic sense as "a pidgin which has become the language of a community," but rather as a language from elsewhere, a language from a colonial homeland or an inter-ethnic lingua franca, which became established in a community which adopted a version of that outside language as a native language and adopted a version of the culture of that outside group as the native culture. The term "creolization" in this sense is associated with loss of a native ethnic identity and replacement of it with a new ethnic identity. It happens in plural societies where several ethnicities combine to make up a new one.

11 James T. Siegel, Fetish, Recognition, Revolution (Princeton, NJ: Princeton University Press, 1997), p. 14.

12 Siegel, Fetish, Recognition, Revolution, p. 18.
} 
the language of modernity, as a symbol which could be used to disassociate themselves from the Pribumi. It must be pointed out that this lingua franca was not isomorphic with the creolized dialects used within the creolized community (in the sense of footnote 3), nor was it isomorphic with the official Malay language propogated by the Dutch and later largely espoused by the nationalists as Indonesian, bahasa Indonesia. This was the variety used as the medium of instruction and associated with school learning, but there are considerable differences between this official Malay and the Melayu used as a lingua franca and in print media. ${ }^{13}$ The Peranakan fastened onto this lingua franca, Melayu, and not onto the standardized and purified Malay. This is clearly documented by the Malay forms found in in-group Peranakan speech. Where the syntax, morphology, and word use of the standard language differs from the lingua franca Melayu, it is the lingua franca Melayu forms and not the standard which appear in the code-switched portions of Peranakan speech: preposed instead of postposed demonstratives, punya in the meaning of "kind, sort," non-standard pronunciations, e.g., marika "they" in place of standard meréka, belon "still" in place of belum, and many others. Some of these special features are loan translations from Melayu into Peranakan Javanese. Note example 5, above, which illustrates the nonstandard preposed demonstrative loan translated into Javanese.

\section{Intertwined Language Mixture}

We need to give further elucidation as to how this intertwining of Javanese and Indonesian-or rather, as we should now term it, this interwining of Javanese with non-standard Melayu-came about. It turns out that the phenomenon of intertwined mixture is widespread throughout the world. The work of Thomason and Kaufman contains examples of the phenomenon and discusses them linguistically. ${ }^{14}$ An explanation of its social origins was first given by Muysken in a discussion of the community of Quechua speakers who had left their home villages to build the railroad in southern Ecuador. ${ }^{15}$ Muysken called the phenomenon "Media Lengua," and its hallmark is that speakers employ Quechua phonology, morphological affixation, and syntactic structure, but use Spanish content words. Not necessarily all Quechua content words are replaced with Spanish; the pattern can vary from quite a number to almost all. Further, one can find interspersed islands of sentences which are expressed in pure Quechua grammatically as well as lexically. The formal parallels between "Media Lengua" and Peranakan Javanese are striking: Peranakan Javanese consists of Javanese phonology, system morphemes, and syntactic structure, but uses Indonesian content morphemes. In other words, Javanese has a place in Peranakan speech completely analogous to the place of Quechua in "Media Lengua." Further, one can find in Peranakan Javanese interspersed switches to pure Javanese, just as there are switches to pure Quechua for the Media Lengua speakers. The development of Media Lengua in Muysken's analysis comes from acts of speaker identity. It arose among rural Quechua speakers who engaged in cyclical migration to the city of Quito and

\footnotetext{
${ }^{13}$ Dede Oetomo, The Chinese of Pasuruan: A Study of Language and Identity in a Minority Community in Transition. PhD Dissertation, Cornell University, 1984. p. 91.

14 Sarah Grey Thomason and Terrence Kaufman, Language Contact, Creolization, and Genetic Linguistics (Berkeley: University of California Press, 1988).

15 Pieter Muysken, "Halfway between Quechua and Spanish: the Case for Relexification," in Historicity and Variation in Creole Stuides, eds. A. Highfield and A. Valdman (Ann Arbor: Karoma, 1981), pp. 52-78.
} 
who wished to set themselves apart from the lower status stay-at-home speakers. But at the same time, they did not identify with the urban Spanish speakers. In short the mixed form is emblematic of in-between identity.

Their history and the current situation in Indonesia furnish ample motivation for Peranakan speakers to keep themselves apart from the Pribumi Javanese speakers. In the Indies the policies of the colonial regime from the eighteenth century on conferred special status on Chinese immigrants and their descendents; subsequently, perhaps consequently, the years of the Indonesian revolution were marked by difficult ethnic relations, and during this time some Pernakan sided with the colonizers. The following years saw a continuation of ethnic tensions which persist to the present day. ${ }^{16}$ The Peranakan needed and continue to need a way to distinguish themselves by speech (as well as other extra-linguistic markers) from the Pribumi. However, the lingua franca Melayu did not clearly indicate their ethnicity. As Siegel points out, Melayu, even among creoles, only weakly defined its speakers' identities, and in any case it indicated a Creole and not a Peranakan identity. ${ }^{17}$ My thesis here is that a mixture very similar in character to that of the Media Lengua developed as a way for the members of the group to identify themselves as Peranakan Chinese. An important component of this identity was the notion of "more sophisticated," "more modern," and the like, which were conveyed by the Melayu forms.

\section{Diglossia and Comparison with Taglish and Student Malay}

To understand the process by which such a language mixture can come to serve as an indicator of identity, let us look at two more examples of interwined languages from Southeast Asia: one from the Philippines and one from Malaysia. The first example "Taglish" developed in the Philippines in the early years of this century as a way for Filipinos of a certain social class to distinguish themselves from the "bakya crowd," the uneducated masses who do not have enough education in English to be able to form meaningful sentences or even phrases with ease. In regions which speak languages other than Tagalog, mixtures of these languages using English in a manner similar to the way it is used in Taglish have developed. As is well known, education in the Philippines has, since the first American occupation, been transmitted largely in English; and although education is nearly universal, only well-off citizens have access to an education sufficiently lengthy and rigorous to allow them to develop a practical control of English. Further, English functions as the main connection with the outside world, much as Melayu did for the population of the Indies in colonial times, and knowledge of English has become emblematic of connections with the outside. Thus speakers use English as a code to display these connections and have done so since English was introduced nearly a century ago. However, to speak English as the Americans do is considered arte "putting on airs." Filipinos who are known to speak nearly accentless and grammatically flawless English will, in settings involving other Filipinos, employ phonology characteristic of a Philippine language and the grammatical structures which characterize English as spoken by Filipinos. In short,

\footnotetext{
${ }^{16}$ Leo Suryadinata, Pribumi Indonesians, the Chinese Minority and China: A Study of Perceptions and Policies (Singapore: Heinemann Asia, 1977).

17 Siegel, Fetish, Recognition, Revolution, p. 14.
} 
English is not a viable code for social interaction among Filipinos ${ }^{18}$ - that is, Filipinos cannot use standard English as the vehicle for negotiating social position or claiming rights of cooperation, nor as a way of giving status or recognizing obligations. To negotiate these interactions Filipino speakers must identify themselves as Filipinos, and in order to do so they must speak a Philippine language (in our example, Tagalog). But when they feel that they must distinguish themselves from the unsophisticated masses, the result is "Taglish" which is a mixture of Tagalog and English, with Tagalog as the matrix language (cf. footnote 7, for the concept "matrix language"). Tagalog thus is analogous to Peranakan Javanese-a Javanese matrix with lingua franca Melayu switches-for the analogous type of elements which are expressed in Melayu among the Peranakan Javanese speakers are expressed in English in Tagalog, and the kind of basic grammatical apparatus which is expressed in Javanese among the Peranakan must be expressed in Tagalog among the Taglish speakers. Note also that Taglish creates an identity of "more sophisticated, more modern," etc., just as the Peranakan language mixture does.

Taglish originated when English began to function as the High variety in a diglossic situation (cf. footnote 18), but in the example we quote below, the English does not occur in a situation typically appropriate for the High form of Diglossia. The High forms not only carry out the diglossic high functions, but they also identify the speaker and the interlocutor as the locus of sophistication. By speaking High, the speaker may state that his interlocutor is sophisticated enough to understand the high forms, and that he himself is sophisticated enough to use them. In other words, the participants in the speech event present themselves as sophisticated by switching into the High form. This imputation of sophistication is part of a strategy for the negotiation of status: the switch indicates that the participants occupy a certain social position implying entitlements and obligations. The switch need not be of long duration. It may be no more than a foray, less than a sentence, and in fact often no longer than a single morpheme. Since the switch is short, it may be engaged in repeatedly, more than once in a single phrase. It is by frequent forays into the High form of diglossia that the High form (in this case the English) becomes intertwined with the Low (Tagalog). At this point the very use of interwined speech becomes emblematic of an identity-that is, the very use of intertwined speech becomes a device for negotiation of status. It presents the speaker as one having certain rights and certain obligations and further attributes rights and obligations to the interlocutor.

The Philippine situation enables us to understand the Peranakan Javanese situation. For the population of the Indies, Melayu functioned commonly as the High variety of Diglossia, just as English does for present-day Filipinos. ${ }^{19}$ When the habit of

\footnotetext{
18 English is used everywhere in functions similar to the High variety of Diglossia , but even when used in these functions there must be Philippine phonology and enough interruptions downward into Tagalog (or whatever the language of the community) to clarify that the speaker and interlocutors are all Filipinos, much as the excursions into Javanese signal Javanese identity among the Pribumi speaking Indonesian (examples 1 and 2, above). See Charles Ferguson, "Diglossia," Word 15 (1959): 325-340. Reprinted in Dell Hymes, ed., Language in Culture and Society (New York: Harper and Row, 1964), pp. 429-439.

${ }^{19}$ Melayu, the lingua franca, has pretty much been replaced by standard Indonesian. I have no recordings of Melayu or even switches into pure Melayu constituents in Peranakan speech. It was used by older speakers who had had little education in standard Indonesian in speaking to non-Javanese and nonPeranakans (and I have been spoken to in this way). Until the Japanese occupation, though, a large portion
} 
switching to Melayu was extended to social contexts, it functioned as a way for the speakers to impute sophistication to themselves or their interlocutors, just as forays into English function in the Philippines, and it is very possible that these switches became short and frequent, as in our Tagalog example, developing the intertwined Melayu-Javanese which we have exemplified. It is our thesis that this interwined speech carried the contextual cues which enabled the participants in the conversation to negotiate status - this speech became emblematic of status of the participants and carried implications of rights and obligations.

The following example from a recording made of a group of women playing Mahjong exemplifies the interwined nature of Taglish and illuminates how we may understand the Peranakan speech. In this case, identity indicated by the interwined speech is not necessarily ethnic, but class based. (It may be a matter of ethnicity for some speakers, since there are members of this community who take pride in having mixed blood, thinking it distinguishes them from the masses who have no mixture of foreign blood.) The example was recorded by M. Bautista. ${ }^{20}$ Words of English origin are spelled as in English, but we have to bear in mind that they are adapted to Tagalog phonology. The mixture of italics and normal type illustrates the intertwined nature of the speech.

\begin{tabular}{|c|c|c|c|}
\hline Mother: & $\begin{array}{l}\text { Ano ba. Madyong na } \\
\text { lang kayo nang } \\
\text { madyong. Ang baby mo } \\
\text { ay iyak nang iyak. }\end{array}$ & $\begin{array}{l}\text { /what question-particle Mahjong } \\
\text { only you and mahjong topic- } \\
\text { marker baby your topic-marker } \\
\text { cry and cry/ }\end{array}$ & $\begin{array}{l}\text { What! all you ever do is play } \\
\text { mahjong. Your baby is crying } \\
\text { and crying. }\end{array}$ \\
\hline Dau & $\begin{array}{l}\text { Inang, pakiasikaso nyo } \\
\text { nga siya. Siguro } \\
\text { kailangan nang diaper at } \\
\text { warm milk. Nananalo ako } \\
\text { dito. Baka mawala ang } \\
\text { luck ko. Please! }\end{array}$ & $\begin{array}{l}\text { /mother please-take-care-of you } \\
\text { please him probably needs object- } \\
\text { marker diaper and warm milk. } \\
\text { Am-winning I here. Lest go-awa } \\
\text { topic-marker luck my. Please./ }\end{array}$ & $\begin{array}{l}\text { Mother, please take care of } \\
\text { him, could you. He probably } \\
\text { needs a new diaper and } \\
\text { warm milk. I'm winning } \\
\text { here. (If I leave the table) I } \\
\text { might run out of luck. Please. }\end{array}$ \\
\hline Play & $\begin{array}{l}\text { You know naiisip ko na } \\
\text { one day I will open a day- } \\
\text { care center. Maraming } \\
\text { nagmamadyong dito but } \\
\text { no one has a good baby- } \\
\text { sitter. }\end{array}$ & $\begin{array}{l}\text { /You know am-thinking I that } \\
\text { one day I will open a day-care } \\
\text { center. Many-who-are playing- } \\
\text { mahjong here, but.... / }\end{array}$ & $\begin{array}{l}\text { You know, I think that one } \\
\text { day I will open a day-care } \\
\text { center. Lots of people play } \\
\text { Mahjong here but no one has } \\
\text { a good baby sitter. }\end{array}$ \\
\hline
\end{tabular}

of published material in Indonesian or Malay was in the lingua franca Melayu, and it persisted in some publications into the 1950's.

${ }^{20}$ Maria Lourdes S. Bautista, The Filipino Bilingual's Competence : A Model Based on anAnalysis of TagalogEnglish Code Switching (Canberra: Research School of Pacific Studies, Australian National University, 1980). 


\begin{tabular}{|c|c|c|c|}
\hline Daughter: & $\begin{array}{l}\text { Oy ang sister ko sa } \\
\text { Manila ay nag-open nang } \\
\text { center because lahat daw } \\
\text { nang kanilang friends ay } \\
\text { iniiwanan ang manga } \\
\text { children sa manga maids. } \\
\text { Lahat ay uneducated. The } \\
\text { whole day wala ang } \\
\text { manga parents. Can you } \\
\text { imagine? Makati is a good } \\
\text { target place, malapit sa } \\
\text { manga eskul, commercial } \\
\text { center, at yuong offices } \\
\text { nang manga parents. }\end{array}$ & $\begin{array}{l}\text { /oy subject-marker sister my at } \\
\text { Manila topic-marker opening } \\
\text { object-marker center because all } \\
\text { they-say of their friends topic } \\
\text { marker are-leaving-behind sub- } \\
\text { ject marker plural children to } \\
\text { plural maids. All topic-marker } \\
\text { uneducated the whole day not- } \\
\text { there topic-marker plural parents } \\
\text { Makati is a good target place near } \\
\text { to plural schools, commercial } \\
\text { center and those office of plural } \\
\text { parents/ }\end{array}$ & $\begin{array}{l}\text { My sister in Manila opened a } \\
\text { center because all of her } \\
\text { friends leave their children } \\
\text { with the maids. All of them } \\
\text { (the maids) are uneducated. } \\
\text { The parents are gone the } \\
\text { whole day. Can you } \\
\text { imagine? Makati is a good } \\
\text { target (for a drop-off center) } \\
\text { because it is close to the } \\
\text { schools, commercial center } \\
\text { and to the parents offices. }\end{array}$ \\
\hline
\end{tabular}

Our final example comes from in-group talk among students at the University of Malaysia. The recording was made in the early 1970s when English was the medium of instruction at the University of Malaysia. Again we see intertwining of English and Malay, which arises from the use of English as a high form in the diglossic situation in the upper echelons of Malay society at the time and on the university campus. The act of establishing identity here is not ethnically based-the participants are all ethnic Malay. Rather by using intertwined speech, the speakers identify themselves as belonging to the group of Malay students studying in an English-medium school. This code is probably ephemeral in nature and has no durability. Nevertheless, the process by which it develops, the motivations for mixing English and Malay, and the intertwined nature of the mixture are analogous to our Peranakan and Taglish examples:

\begin{tabular}{|r|l|l|l|}
\hline A: & $\begin{array}{l}\text { Bukalah cis tu macam } \\
\text { mane nak makan }\end{array}$ & $\begin{array}{l}\text { /open-come-on cheese } \\
\text { that manner how will } \\
\text { eat/ }\end{array}$ & $\begin{array}{l}\text { Open the cheese. How can we eat it (if you } \\
\text { don't open it)? }\end{array}$ \\
\hline $\mathrm{M}:$ & $\begin{array}{l}\text { A Sharifah katup dulu } \\
\text { ba r u I boleh cakap } \\
\text { Sharifah ooi..Sharifah }\end{array}$ & $\begin{array}{l}\text { /A Sharifah close first } \\
\text { before I can speak..../ }\end{array}$ & $\begin{array}{l}\text { Sharifah I can't talk until you close it. Hey } \\
\text { Sharifah. }\end{array}$ \\
\hline $\mathrm{S}:$ & Ye & $\begin{array}{l}\text { Kate my rumét ye } \\
\text { /said my roommate } \\
\text { you-know/ }\end{array}$ & My roomate said... \\
\hline $\begin{array}{l}\text { Kate my rumét die fifty } \\
\text { sens aje kate die, mo then } \\
\text { inaf tak temakan kate die }\end{array}$ & $\begin{array}{l}\text { /said my roommate she } \\
\text { fifty cents only says she } \\
\text { more than enough not } \\
\text { can-eat says she/ }\end{array}$ & $\begin{array}{l}\text { My roomate says she only has fifty cents. } \\
\text { can't get anything to eat for that. }\end{array}$ \\
\hline
\end{tabular}




\begin{tabular}{|c|c|c|c|}
\hline & $\begin{array}{l}\text { io pe fifty sens only kate } \\
\text { die }\end{array}$ & $\begin{array}{l}\text { /yes have fifty sens only } \\
\text { says she/ }\end{array}$ & She says she only has fifty cents. \\
\hline & én wi héf lot of fut & & And we have lots of food. \\
\hline A & Ala, bohong la & /God lie believe-me/ & God, that's a lie. \\
\hline $\mathrm{H}:$ & $\begin{array}{l}\text { Ngkau-punye fréshis } \\
\text { berape banyak on this } \\
\text { floo? }\end{array}$ & $\begin{array}{l}\text { /your freshies how } \\
\text { many on this floor/ }\end{array}$ & How many freshmen are on this floor? \\
\hline A & due belas & & Twelve. \\
\hline $\mathrm{H}:$ & aku-punye fréshis tên & /my freshies ten/ & We have ten. \\
\hline A: & Banyaknye & & What a lot! \\
\hline I. & $\begin{array}{l}\text { Wial-punye flo lagi satu } \\
\text { bende takde }\end{array}$ & $\begin{array}{l}\text { /our floor more one } \\
\text { thing is-not-there/ }\end{array}$ & $\begin{array}{l}\text { Our floor is still lacking one thing (for a } \\
\text { party). }\end{array}$ \\
\hline & Miting pun takde & $\begin{array}{l}\text { /meeting even is-not- } \\
\text { there/ }\end{array}$ & We don't have (stuff for) a meeting either. \\
\hline $\mathrm{S}$ & $\begin{array}{l}\text { Kite-orang é top dah } \\
\text { dapat invitéshen }\end{array}$ & $\begin{array}{l}\text { /we hear-me tops } \\
\text { already got invitation/ }\end{array}$ & $\begin{array}{l}\text { We're the tops. We have already gotten an } \\
\text { invitation. }\end{array}$ \\
\hline A & $\begin{array}{l}\text { kita due-due di top é top } \\
\text { punya bukan-main ni } \\
\text { popule diman }\end{array}$ & $\begin{array}{l}\text { /we both on top hear- } \\
\text { me top kind very-much } \\
\text { this popular demand/ }\end{array}$ & $\begin{array}{l}\text { Both of us are the tops. We are terribly in } \\
\text { popular demand. }\end{array}$ \\
\hline
\end{tabular}

In conclusion, the Peranakan Chinese of Central Java identify themselves ethnically by speech forms. This is accomplished most significantly through the interwined Melayu-Javanese code, which has its origin in a diglossic situation where the lingua franca Melayu functioned as a High code. As is typical of high codes in the diglossic situation, this code is invoked to lend substance to what is said and present the speaker and the interlocutor as sophisticated. The intertwined form comes about from frequent switches into this High code of diglossia; participants in a conversation employ these switches to connote sophistication. In a process analogous to that which gives rise to Media Lengua in Ecuador, Taglish in the Philippines, and Malay student talk among students at the University of Malaysia in the 1970s, this intertwined Melayu-Javanese has evolved into a device for denoting ethnic identity and thus has become a means for negotiating in-group cooperation. The hypothesis that this mixture of Melayu originates in the role Melayu played as the High variety in a diglossic situation is substantiated by the fact that analysis of current interactions shows that the amount of material of Melayu provenience increases as the speaker needs to show respect for status or show care with the interlocutor. If one measures how frequently speakers employ this in-group, intertwined language, that measurement gives some idea of the degree of integration of the Peranakan and the Pribumi in Indonesia. It may be predicted that as the need for the Peranakan to identify themselves as a separate group declines, the use of this form of intertwined speech will also decline. 
44 John U. Wolff

\section{References}

Bakker, Peter and Maarten Mous, eds. 1994. “Mixed Languages: 15 Case Studies in Language Intertwining," Studies in Language and Language Use, No. 13. Amsterdam: Institute for Functional Research into Language and Language Use.

Bautista, Maria Lourdes S. 1980. The Filipino Bilingual's Competence : A Model Based on an Analysis of TagalogEnglish Code Switching. Canberra: Research School of Pacific Studies, Australian National University.

Brown, R. and A. Gillman. 1960. "The pronoun of power and solidarity." T. Sebeok, ed. Style in Language. Cambridge, MA: MIT Press.

Ferguson, Charles. "Diglossia," Word 15 (1959). Reprinted in Dell Hymes, ed., Language in Culture and Society. New York: Harper and Row, 1964.

Gumperz, John. 1982. Discourse Strategies. Chapter 3: "Social Network and Language Shift." Cambridge: Cambridge University Press.

Le Page, R. B. and Andrée Tabouret-Keller. 1985. Acts of identity: Creole-based approaches to language and ethnicity. Cambridge: Cambridge University Press.

Maier, H. M. J. 1993. "From heteroglossia to polyglossia: the creation of Malay and Dutch in the Indies," Indonesia 56 (October 1993).

Muysken, Pieter. 1981. "Halfway between Quechua and Spanish: the Case for Relexification," in Historicity and Variation in Creole Stuides, eds. A. Highfield and A. Valdman. Ann Arbor: Karoma.

Myers-Scotton, Carol. 1993. "Social and Structural Factors in Codeswitching." Language in Society 22.

Oetomo, Dede. 1991. "The Chinese of Indonesia and the development of the Indonesian language." Indonesia, Special Publications: Proceedings of a symposium held at Cornell University in conjunction with the Southeast Asian Studies Summer Institute, July 13-15, 1990.

- The Chinese of Pasuruan: A Study of Language and Identity in a Minority Community in Transition. PhD Dissertation, Cornell University, 1984.

Rafferty, E. 1978. "Studies in the discourse of the Indonesian of the Chinese of Malang, East Java, Indonesia." Jakarta: Nusa 12.

_. 1983. “National language ability: a sociolinguistic survey in East Java, Indonesia." Journal of Southeast Asian Studies 14.1.

Siegel, James T. 1997. Fetish, Recognition, Revolution. Princeton, NJ: Princeton University Press.

Suryadinata, Leo. 1977. Pribumi Indonesians, the Chinese Minority and China: A Study of Perceptions and Policies Singapore: Heinemann Asia.

Thomason, Sarah Grey and Terrence Kaufman. 1988. Language Contact, Creolization, and Genetic Linguistics. Berkeley: University of California Press.

Wolff, John U. and Soepomo Poedjosoedarmo. 1982. Communicative Codes in Central Java. Data Paper Number 116, Linguistics Series VIII. Ithaca, NY: Cornell Southeast Asia Program. 